\title{
Sex differences in soluble prorenin receptor in patients with type 2 diabetes
}

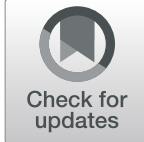

\author{
Bruna Visniauskas ${ }^{1 \dagger}$, Danielle Y. Arita ${ }^{1 \dagger}$, Carla B. Rosales ${ }^{1}$, Mohammed A. Feroz ${ }^{1}$, Christina Luffman ${ }^{1}$, \\ Michael J. Accavitti', Gabrielle Dawkins', Jennifer Hong ${ }^{1}$, Andrew C. Curnow ${ }^{1}$, Tina K. Thethi ${ }^{2,3}$, John J. Lefante ${ }^{4}$, \\ Edgar A. Jaimes ${ }^{5}$, Franck Mauvais-Jarvis ${ }^{2,6,7}$, Vivian A. Fonseca ${ }^{2,6}$ and Minolfa C. Prieto ${ }^{1,8^{*}}$ (D)
}

\begin{abstract}
Background: The soluble prorenin receptor (SPRR), a member of the renin-angiotensin system (RAS), is elevated in plasma of patients with preeclampsia, hypertension, chronic kidney disease (CKD), and type 2 diabetes. Our goal was to examine the relationship between sPRR and RAS activation to define whether sexual dimorphisms in sPRR might explain sex disparities in renal outcomes in patients with type 2 diabetes.

Methods: Two hundred sixty-nine participants were included in the study (mean age, $48 \pm 16$ years; 42\% men, 58\% women), including 173 controls and 96 subjects with type 2 diabetes. In plasma and urine, we measured sPRR, plasma renin activity (PRA), and prorenin. In the urine, we also measured angiotensinogen along with other biomarkers of renal dysfunction.

Results: Plasma sPRR and PRA were significantly higher in women with type 2 diabetes compared to men. In these women, plasma sPRR was positively correlated with PRA, age, and body mass index (BMI). In contrast, in men the sPRR in urine but not in plasma positively correlated with eGFR in urine, but negatively correlated with urine renin activity, plasma glucose, age, and BMI.

Conclusions: In patients with type 2 diabetes, sPRR contributes to RAS stimulation in a sex-dependent fashion. In diabetic women, increased plasma sPRR parallels the activation of systemic RAS; while in diabetic men, decreased sPRR in urine matches intrarenal RAS stimulation. sPRR might be a potential indicator of intrarenal RAS activation and renal dysfunction in men and women with type 2 diabetes.
\end{abstract}

Keywords: Plasma renin activity, Urine renin activity, eGFR, Urine angiotensinogen, Sexual dimorphism

\section{Introduction}

Type 2 diabetes mellitus is a major risk factor for cardiovascular $(\mathrm{CV})$ and renal diseases [1]. A high percentage of patients with type 2 diabetes exhibit inappropriate activation of systemic and intrarenal renin-angiotensin systems (RAS) [2], which increases the risk of acute

\footnotetext{
* Correspondence: mprieto@tulane.edu

${ }^{\dagger}$ Bruna Visniauskas and Danielle Y. Arita contributed equally to this work.

'Department of Physiology, Tulane University School of Medicine, 1430

Tulane Avenue, SL39, New Orleans, LA 70112, USA

${ }^{8}$ Tulane Hypertension and Renal Center of Excellence, Tulane University School of Medicine, New Orleans, LA, USA

Full list of author information is available at the end of the article
}

coronary events and accelerate the progression of diabetic nephropathy (DN) to chronic kidney disease (CKD) [3], particularly in menopausal women with type 2 diabetes [4]. Identifying a novel candidate biomarker that reflects systemic and intrarenal RAS status is crucial for reducing the prevalence of $\mathrm{CV}$ events and the progression of $\mathrm{DN}$.

In 2002, Nguyen et al. [5] cloned the prorenin receptor (PRR), a single transmembrane domain protein that fully activates prorenin and enhances the catalytic activity of renin $[6,7]$. PRR-dependent activation of prorenin catalyzes the conversion of angiotensinogen (AGT) to

(c) The Author(s). 2021 Open Access This article is licensed under a Creative Commons Attribution 4.0 International License, which permits use, sharing, adaptation, distribution and reproduction in any medium or format, as long as you give appropriate credit to the original author(s) and the source, provide a link to the Creative Commons licence, and indicate if changes were made. The images or other third party material in this article are included in the article's Creative Commons licence, unless indicated otherwise in a credit line to the material. If material is not included in the article's Creative Commons licence and your intended use is not permitted by statutory regulation or exceeds the permitted use, you will need to obtain permission directly from the copyright holder. To view a copy of this licence, visit http://creativecommons.org/licenses/by/4.0/ The Creative Commons Public Domain Dedication waiver (http://creativecommons.org/publicdomain/zero/1.0/) applies to the data made available in this article, unless otherwise stated in a credit line to the data. 
angiotensin-I (Ang-I), which is a key process in the RAS cascade [5]. Furthermore, the binding of prorenin to PRR stimulates tissue profibrotic genes, independent of the RAS $[8,9]$. In humans, rats, and mice, PRR is expressed in various tissues, including the brain, heart, fat, blood vessels, placenta, lung, and kidney [5, 10-12]. In the kidney, PRR is upregulated in diabetes [13] and its inhibition ameliorates DN $[14,15]$. Besides a membrane-bound isoform, the PRR exhibits a soluble isoform (sPRR) that is processed intracellularly by various serine proteases [16-18]. The levels of sPRR are increased in the plasma of patients with essential hypertension, preeclampsia, gestational diabetes, obstructive sleep apnea, DN, and CKD [19-22]. However, the relationship between SPRR and renal dysfunction in patients with type 2 diabetes remains unclear.

In patients with type 2 diabetes, high circulating levels of prorenin are associated with the onset of microalbuminuria [23] and the onset of microvascular complications $[24,25]$. The ability of sPRR to activate prorenin in the extracellular space raises the possibility that the interactions between sPRR and prorenin in the systemic circulation, or within the renal intratubular compartments, may contribute to either systemic or intrarenal RAS activation and the progression of CKD in patients with type 2 diabetes [11,26]. Sex also influences fasting glucose and glucose tolerance responses through gonadal hormones controlling glucose homeostasis [27]. In type 2 diabetes, dysregulation of the RAS contributes to the development of diabetic kidney disease and CV complications. While premenopausal women are protected from these complications, the protection weakens after menopause and even more in those with type 2 diabetes $[28,29]$. However, it is unknown whether sex differences in sPRR concentrations in plasma and/or urine are associated with renal dysfunction in patients with type 2 diabetes. In the present study, we examined the effects of sex on plasma and urine sPRR concentrations, and their relationship with systemic RAS activation and decline in renal function in a cohort of men and women with type 2 diabetes.

\section{Material and methods}

\section{Study participants}

This was a randomized and cross-sectional study that enrolled 269 individuals at Tulane University Health Sciences Center and all participants were enrolled from November 2008 to June 2012. The inclusion criteria were male or female of age $>18$ years old. Participants that self-reported history of drug abuse or pregnancy were excluded from the study. During the first visit, a complete medical history was obtained, and a physical exam was performed. From each patient, $5 \mathrm{~mL}$ of fasting blood was drawn into EDTA- containing tubes, placed on ice, centrifuged within 10 $\mathrm{min}$ in a refrigerated centrifuge at $1300 \times g$ for $10 \mathrm{~min}$, to collect plasmas which were then snap frozen in liquid nitrogen, and stored in $-80{ }^{\circ} \mathrm{C}$ freezer until assayed. The time interval between blood sampling and centrifugation was minimized to prevent false positive increases in sPRR levels as well as renin activity. In patients with history of type 2 diabetes, hemoglobin A1c (HbA1c) was measured as well. Similarly, quickly after urine collection, samples were centrifuged at $1300 \times g$ at $4{ }^{\circ} \mathrm{C}$ for $10 \mathrm{~min}$, and then stored in $-80{ }^{\circ} \mathrm{C}$ freezer until assayed

\section{Background factors and laboratory data at enrollment}

Age, sex, race, BMI, waist-to-hip ratio (WHR), fasting blood glucose, blood pressure, and plasma creatinine levels were measured using standard laboratory methods at the Tulane Clinical Science Center. The estimated glomerular filtration rate (eGFR) was calculated using a prediction equation developed from the Modification of Diet in Renal Disease study [30].

The concentration of sPRR measured by ELISA (\#27782, IBL America, Minneapolis, MN) and renin activity by radioimmunoassay (\#CA1553, DiaSorin Inc, Stillwater, MN). In the urine, we quantified the concentrations of creatinine and albumin to creatinine ratio (ACR) (DCA-2000, Bayer AG, Germany), and angiotensinogen (uAGT) and transforming growth factor-beta 1 (TGF- $\beta 1$ ) concentrations were quantified by ELISA kits (\#24412, IBL America; \#MB100B, R\&D Systems, Minneapolis, MN). Urine samples were concentrated ten-fold using Amicon Ultra-10 centrifugal filters (Millipore, Massachusetts, USA) before the quantification of prorenin (\#IHPREN-HIS, Molecular Innovations, Novi, MI).

\section{Statistical analyses}

The values were expressed as means and SD or 95\% confident intervals for continuous variables. The cohort was divided into 2 groups: control group (participants with no personal history of diabetes) and patients with type 2 diabetes (for those with history of type 2 diabetes). One-way analysis of variance followed by Bonferroni comparisons and unpaired $t$ tests were used to compare continuous variables between groups. Pearson correlation coefficients were performed to determine associations between plasma, urine SPRR, and the background factors. The relationship between eGFR (a continuous outcome) and sPRR variables was evaluated using multiple linear regression models. The levels of significance were defined as $P<0.05$. All analyses were performed using SAS v9.4. 


\section{Results}

Demographic characteristics of the study participants Table 1 shows demographic and clinical characteristics of the participants. Of the 269 participants, 112 were men (63\% controls and 37\% with type 2 diabetes), and 157 were women (65\% controls and 35\% with type 2 diabetes). The mean age was significantly higher in participants with type 2 diabetes (55 \pm 9 vs. control $39 \pm 13$ years old). Patients with type 2 diabetes were obese (BMI $37.5 \pm 7.4 \mathrm{~kg} / \mathrm{m}^{2}$ ), whereas control participants were overweight $\left(28 \pm 7.9 \mathrm{~kg} / \mathrm{m}^{2}\right)$. Patients with type 2 diabetes exhibited higher glucose levels, HbA1c (7.6 \pm $2 \%$ for subjects with diabetes), and ACR (76 $\pm 79 \mathrm{mg} / \mathrm{g})$. The average eGFR was significantly lower $(83 \pm 26$ vs. control $\left.95 \pm 21 \mathrm{~mL} / \mathrm{min} / 1.73 \mathrm{~m}^{2} ; P=0.01\right)$ and creatinine significantly higher $(0.5 \pm 0.2$ vs. control $0.7 \pm 0.4$ $\mathrm{mg} / \mathrm{L} ; P=0.001$ ), in participants with type 2 diabetes. Anti-hypertensive medications among of participants with type 2 diabetes include angiotensin receptors blockers (ARBs), angiotensin-converting enzyme inhibitors ( $\mathrm{ACEi}), \beta$-adrenergic blockers, calcium channel blockers, or diuretics. Patients with type 2 diabetes were on treatment with diabetic medications consisting of (combination of) insulin, metformin, dipeptidyl peptidase-4 inhibitors, glucagon-like peptide 1 receptor agonist, sulfonylureas, and thiazolidinediones.

\section{Soluble PRR levels, renin activity, and uAGT levels and excretion display sex differences in patients with type 2 diabetes}

Table 2 summarizes the levels of plasma and urine concentrations of sPRR, renin activity, and urine prorenin amount and urinary excretion of AGT and TGF- $\beta 1$ in men and women from both groups.

\section{Plasma and urine sPRR}

Plasma sPRR was significantly elevated in participants with type 2 diabetes and to a greater extent in men compared to women, albeit by a small, but statistically significant, amount. Notably, plasma sPRR did not differ

Table 1 Demographic, clinical characteristics, demographic, and medications

\begin{tabular}{|c|c|c|c|c|c|c|}
\hline \multirow[t]{2}{*}{ Variables } & \multicolumn{2}{|c|}{ Total participants } & \multicolumn{2}{|l|}{ Men } & \multicolumn{2}{|l|}{ Women } \\
\hline & Control & Type 2 diabetes & Control & Type 2 diabetes & Control & Type 2 diabetes \\
\hline Participants, $n$ (\%) & $173(64)$ & $96(36)$ & $71(63)$ & $41(37)$ & $102(65)$ & $55(35)$ \\
\hline Age & $39(13)$ & $55(9)$ & $40(13)$ & $56(8)$ & $39(13)$ & $55(10)$ \\
\hline Caucasians, n (\%) & $114(42)$ & $44(16)$ & $44(16)$ & $19(7)$ & $70(26)$ & $25(9)$ \\
\hline African American, $n$ (\%) & $59(22)$ & $52(20)$ & $27(55)$ & $22(45)$ & $32(51)$ & $30(49)$ \\
\hline \multicolumn{7}{|l|}{ Clinical analysis } \\
\hline BMI $\left(\mathrm{kg} / \mathrm{m}^{2}\right)$ & $28(7.9)$ & $37.5(7.4)$ & $28(6.9)$ & $38(7)$ & $28(8.6)$ & $37(7.8)$ \\
\hline WHR & $0.8(0.1)$ & $0.9(0.1)$ & $0.91(0.08)$ & $1.0(0.05)$ & $0.81(0.07)$ & $0.89(0.1)$ \\
\hline $\mathrm{SBP}(\mathrm{mm} \mathrm{Hg})$ & $118(15)$ & $132(22)$ & $121(14)$ & $133(25)$ & $116(15)$ & $131(20)$ \\
\hline $\mathrm{DBP}(\mathrm{mm} \mathrm{Hg})$ & $74(11)$ & $80(12)$ & $74(12)$ & $80(14)$ & $73(12)$ & $80(12)$ \\
\hline Fasting glucose (mg/dL) & $77(19)$ & $134(54)$ & $82(18)$ & $150(54)$ & $75(19)$ & $122(51)$ \\
\hline $\mathrm{HbA1C}(\%)$ & - & $7.6(1.7)$ & - & $8.3(2)$ & - & $7.2(1)$ \\
\hline Serum creatinine (mg/dL) & $0.85(0.1)$ & $1.2(1.9)$ & $0.98(0.15)$ & $1.67(2.9)$ & $0.75(0.1)$ & $0.83(0.2)$ \\
\hline ACR (mg albumin/gCr) & $28(26)$ & $76(79)$ & $27(29)$ & $78(77)$ & $29(23)$ & $74(82)$ \\
\hline uCreatinine (mg/L) & $0.7(0.4)$ & $0.5(0.2)$ & $0.7(0.4)$ & $0.6(0.2)$ & $0.7(0.4)$ & $0.5(0.2)$ \\
\hline eGFR $\left(\mathrm{mL} / \mathrm{min}\right.$ per $\left.1.73 \mathrm{~m}^{2}\right)$ & $95(21)$ & $83(26)$ & $94(17)$ & $77(28)$ & $95(23)$ & $87(24)$ \\
\hline \multicolumn{7}{|l|}{ Medications } \\
\hline No meds, $n(\%)$ & $169(63)$ & $25(9)$ & $69(62)$ & $10(9)$ & $99(63)$ & $15(9)$ \\
\hline ARB, $n(\%)$ & - & $13(5)$ & - & $5(5)$ & - & $8(5)$ \\
\hline $\mathrm{ACEi}, n(\%)$ & $2(1)$ & $30(11)$ & $2(2)$ & $12(10)$ & $3(2)$ & $18(11)$ \\
\hline ARB/ACEi, $n(\%)$ & - & $4(1)$ & - & $3(3)$ & - & $1(1)$ \\
\hline$\beta$-adrenergic blockers, $n$ (\%) & $2(1)$ & $19(7)$ & - & $11(10)$ & - & $8(5)$ \\
\hline Calcium channel blockers, $n$ (\%) & - & $1(1)$ & - & - & - & $1(1)$ \\
\hline Diuretics, $n(\%)$ & - & $4(2)$ & - & - & - & $4(3)$ \\
\hline Diabetes medication, $n(\%)$ & $1(0.4)$ & $80(30)$ & $1(1)$ & $35(32)$ & - & $46(29)$ \\
\hline
\end{tabular}

Data are expressed as mean (SD). ARB angiotensin-Il type 1 receptor blocker, ACEi angiotensin-converting I enzyme inhibitors. Anti-diabetic medications include insulin, metformin, dipeptidyl peptidase-4 inhibitors, glucagon-like peptide 1 receptor agonist, sulfonylureas, and thiazolidinediones 
Table 2 Soluble PRR, renin, prorenin, AGT, and TGF- $\beta 1$ in plasma and urine

\begin{tabular}{|c|c|c|c|c|c|c|c|c|c|}
\hline \multirow[t]{2}{*}{ Variables } & \multicolumn{3}{|c|}{ Total participants } & \multicolumn{3}{|l|}{ Men } & \multicolumn{3}{|l|}{ Women } \\
\hline & Control & $\begin{array}{l}\text { Type } 2 \\
\text { diabetes }\end{array}$ & $P$ value & Control & $\begin{array}{l}\text { Type } 2 \\
\text { diabetes }\end{array}$ & $P$ value & Control & $\begin{array}{l}\text { Type } 2 \\
\text { diabetes }\end{array}$ & $P$ value \\
\hline \multicolumn{10}{|l|}{ Plasma } \\
\hline sPRR (ng/mL) & $\begin{array}{l}16.5 \\
(15.8-17)\end{array}$ & $19.2(17-21)^{*}$ & 0.001 & $\begin{array}{l}18 \\
(16.5-19)\end{array}$ & $17(16-20)$ & 0.87 & $\begin{array}{l}15(14.8- \\
16)+\end{array}$ & $20(18-22) \neq$ & $\begin{array}{l}{ }^{\dagger} 0.05 \\
{ }^{\ddagger} 0.001\end{array}$ \\
\hline $\begin{array}{l}\text { Renin activity (ng Ang-l } \\
/ \mathrm{mL} / \mathrm{h} \text { ) }\end{array}$ & $\begin{array}{l}3.2 \\
(2.7-3.8)\end{array}$ & $12(10-14)^{*}$ & 0.001 & $\begin{array}{l}3.5 \\
(2.5-4.5)\end{array}$ & $9.8(6.4-13.3)^{\dagger \neq * *}$ & $\begin{array}{l}{ }^{\dagger} 0.001 \\
{ }^{\ddagger} 0.001 \\
{ }^{*} 0.05\end{array}$ & $3.0(2.3-3.7)$ & $\begin{array}{l}13(11- \\
15.6)^{\dagger \neq}\end{array}$ & $\begin{array}{l}{ }^{\dagger} 0.001 \\
{ }^{\ddagger} 0.001\end{array}$ \\
\hline \multicolumn{10}{|l|}{ Urine } \\
\hline sPRR/uCr (ng/mg) & $\begin{array}{l}1.6 \\
(1.3-1.8)\end{array}$ & $0.8(0.6-1)^{*}$ & 0.001 & $\begin{array}{l}1.8 \\
(1.4-2.4)\end{array}$ & $0.6(0.4-0.8)^{\dagger \neq}$ & $\begin{array}{l}{ }^{\dagger} 0.001 \\
{ }^{\ddagger} 0.05\end{array}$ & $1.3(1-1.7)$ & $\begin{array}{l}1.0(0.75- \\
1.3)+\end{array}$ & ${ }^{\dagger} 0.001$ \\
\hline $\begin{array}{l}\text { Renin activity (ng Ang-I } \\
/ \mathrm{mL} / \mathrm{h} \text { ) }\end{array}$ & $\begin{array}{l}27 \\
(21-33)\end{array}$ & $99(77-120)^{*}$ & 0.001 & $\begin{array}{l}27 \\
(16.5-37.4)\end{array}$ & $125(82-168)^{\dagger \neq * *}$ & $\begin{array}{l}{ }^{\dagger} 0.001 \\
{ }^{\ddagger} 0.001 \\
{ }^{*} 0.05\end{array}$ & $27(20-34)$ & $\begin{array}{l}84(60- \\
108)^{\dagger \neq}\end{array}$ & $\begin{array}{l}{ }^{\dagger} 0.001 \\
{ }^{\ddagger} 0.001\end{array}$ \\
\hline Prorenin/uCr (ng/g) & $\begin{array}{l}141 \\
(109-173)\end{array}$ & $302(232-371)^{*}$ & 0.01 & $\begin{array}{l}128 \\
(91-165)\end{array}$ & $362(215-508)^{\dagger \neq}$ & $\begin{array}{l}{ }^{\dagger} 0.01 \\
{ }^{\ddagger} 0.05\end{array}$ & $\begin{array}{l}153 \\
(103-204)\end{array}$ & $\begin{array}{l}273 \\
(199-348)^{+}\end{array}$ & ${ }^{\dagger} 0.01$ \\
\hline AGT/uCr $(\mu \mathrm{g} / \mathrm{g})$ & $\begin{array}{l}16 \\
(13-19)\end{array}$ & $25(17-32)^{*}$ & 0.02 & $15(11-20)$ & $30(17-42)^{\dagger \neq}$ & $\begin{array}{l}{ }^{\dagger} 0.05 \\
{ }^{\ddagger} 0.05\end{array}$ & $16(12-20)$ & $21(11-20)$ & 0.52 \\
\hline TGF- $\beta 1 / u C r(p g / m g)$ & $\begin{array}{l}18 \\
(14-22)\end{array}$ & $31(24-38)^{*}$ & 0.001 & $16(11-21)$ & $33(20-45)^{\dagger}$ & ${ }^{\dagger} 0.05$ & $19(13-25)$ & $31(23-39)^{\dagger}$ & ${ }^{\dagger} 0.05$ \\
\hline
\end{tabular}

Data are shown as mean (95\% confident intervals). ${ }^{*}$ Different from total participants' control; ${ }^{\dagger}$ Different from men control; ${ }^{\ddagger}$ Different from women control.

** Different from women with type 2 diabetes

between male controls and subjects with diabetes. However, plasma sPRR concentration was augmented in women with type 2 diabetes compared to controls. In contrast, urinary concentrations of SPRR were significantly lower in diabetics, in both men and women compared to controls (Table 2).

\section{Renin activity in plasma and urine}

Plasma renin activity (PRA) was significantly higher in participants with type 2 diabetes compared to controls. In men and women analyzed separately, PRA was significantly increased in subjects with diabetes compared to controls and was higher in men than in women. Similarly, the renin activity was increased in the urine of subjects with type 2 diabetes compared to controls. Both women and men showed increased urine renin activity; however, the increase was greater in men than in women with type 2 diabetes (Table 2).

\section{Prorenin amount in urine}

After ten-fold concentration, prorenin amount in urine was measured and detected in $63 \%$ of controls and $84 \%$ of patients with type 2 diabetes. Prorenin was augmented in the urine of subjects with type 2 diabetes compared to controls. Although the concentrations of prorenin did not display sex differences between controls from both sexes, in subjects with type 2 diabetes the urine prorenin concentration was greater in men than in women (Table 2).

\section{Urinary AGT excretion (UAGT)}

The positive correlation between increased intrarenal RAS activity and risk of CKD has been indicated by the increases in UAGT of human subjects $[2,31]$. In this cohort, men with type 2 diabetes exhibited significantly higher uAGT than controls, whereas no significant differences were found between women with type 2 diabetes (Table 2).

\section{Urinary TGF- $\beta 1$ excretion}

Previous studies have indicated that prorenin-dependent activation of PRR bound to cell membranes may contribute to the stimulation of downstream signals as TGF- $\beta 1$ [14]. Therefore, we quantified the levels of TGF- $\beta 1$ in the urine. TGF- $\beta 1$ was increased in patients with type 2 diabetes compared to controls. There were no sex differences observed among groups (Table 2).

\section{Correlations between sPRR concentrations and markers of renal function}

Age, BMI, and PRA were positively correlated with plasma SPRR in all participants. However, when analyzed by sex, this correlation remained significant only for women. In addition, eGFR displayed was negatively correlated with plasma sPRR in women, but not in men (Table 3).

In the entire cohort, urine sPRR was negatively correlated with age and ACR, but when this correlation was analyzed by sex, it remained significant only in men. Likewise, urine renin activity was negatively correlated 
Table 3 Correlations between plasma and urine sPRR and risk factors for type 2 diabetes in participants

\begin{tabular}{|c|c|c|c|c|c|c|c|c|c|}
\hline \multirow[t]{2}{*}{ Variables } & \multicolumn{3}{|c|}{ Total participants } & \multicolumn{3}{|l|}{ Men } & \multicolumn{3}{|l|}{ Women } \\
\hline & $r$ & $P$ value & $n$ & $r$ & $P$ value & $n$ & $r$ & $P$ value & $n$ \\
\hline \multicolumn{10}{|l|}{ Plasma } \\
\hline Age & 0.181 & 0.001 & 244 & 0.102 & 0.311 & 101 & 0.224 & 0.007 & 143 \\
\hline BMI & 0.150 & 0.020 & 244 & 0.097 & 0.334 & 101 & 0.179 & 0.032 & 143 \\
\hline DBP & 0.067 & 0.3003 & 240 & 0.121 & 0.231 & 99 & 0.031 & 0.723 & 141 \\
\hline SBP & 0.008 & 0.0866 & 240 & 0.081 & 0.424 & 99 & 0.080 & 0.343 & 141 \\
\hline Glucose & 0.084 & 0.1997 & 233 & 0.002 & 0.983 & 97 & 0.132 & 0.124 & 136 \\
\hline $\mathrm{HbA1c}$ & -0.087 & 0.464 & 80 & -0.204 & 0.278 & 37 & 0.032 & 0.838 & 42 \\
\hline Plasma renin activity & 0.273 & $<0.001$ & 187 & 0.145 & 0.222 & 72 & 0.499 & $<0.001$ & 115 \\
\hline Urine renin activity & 0.114 & 0.1104 & 196 & 0.171 & 0.135 & 78 & 0.071 & 0.442 & 118 \\
\hline$A C R$ & 0.061 & 0.3543 & 232 & 0.084 & 0.418 & 95 & -0.068 & 0.443 & 129 \\
\hline eGFR & -0.147 & 0.024 & 233 & 0.033 & 0.745 & 97 & -0.235 & 0.005 & 137 \\
\hline \multicolumn{10}{|l|}{ Urine } \\
\hline Age & -0.240 & $<0.001$ & 233 & -0.433 & $<0.001$ & 101 & -0.094 & 0.282 & 132 \\
\hline BMl & -0.109 & 0.0969 & 233 & -0.259 & 0.001 & 101 & 0.014 & 0.873 & 132 \\
\hline DBP & -0.124 & 0.0607 & 230 & -0.149 & 0.140 & 99 & -0.109 & 0.215 & 131 \\
\hline SBP & -0.052 & 0.4251 & 230 & -0.033 & 0.742 & 99 & -0.081 & 0.354 & 131 \\
\hline Glucose & -0.266 & $<0.001$ & 220 & -0.404 & $<0.001$ & 96 & -0.137 & 0.127 & 124 \\
\hline $\mathrm{HbA1c}$ & -0.011 & 0.924 & 78 & -0.053 & 0.773 & 32 & 0.119 & 0.429 & 46 \\
\hline Plasma renin activity & -0.0853 & 0.2660 & 173 & -0.007 & 0.951 & 71 & -0.124 & 0.213 & 102 \\
\hline Urine renin activity & -0.310 & $<0.001$ & 185 & -0.330 & $<0.001$ & 78 & -0.292 & 0.002 & 108 \\
\hline$A C R$ & -0.140 & 0.036 & 222 & -0.157 & 0.130 & 94 & 0.085 & 0.357 & 120 \\
\hline eGFR & 0.183 & 0.006 & 221 & 0.276 & 0.006 & 96 & 0.113 & 0.208 & 125 \\
\hline TFG- $\beta$ & 0.081 & 0.371 & 123 & -0.193 & 0.188 & 48 & 0.310 & 0.007 & 75 \\
\hline
\end{tabular}

with sPRR in urine of men and women from the control group. Additionally, urine sPRR was negatively correlated with age, fasting glucose, and eGFR in men. However, in women, a positive correlation was only observed between sPRR levels and TGF- $\beta 1$ in urine. HbA1c did not correlate with sPRR concentrations in plasma and urine.

eGFR rate is associated with sPRR levels and renin activity in plasma and urine

Multiple linear regression analyses in all the participants were performed to determine if the relationship between plasma and urine sPRR levels, renin activity, and eGFR (Table 4). Model 1 represents the simple regression analysis between eGFR, urine renin activity, and SPRR in plasma and urine. Model 2 represents the relationships between eGFR and levels of sPRR in plasma and urine after adjusting for diabetes, age, sex, race, body weight, BMI, DBP, SBP, anti-hypertensives, and diabetic medication. Using these two models, we found a significant association between eGFR, plasma and urine sPRR, urine renin activity, and age, race, and anti-hypertensive. Also, body weight was significantly associated in urine renin activity and urine sPRR.

Sex effect on renin activity, SPRR, and prorenin in patient with type 2 diabetes by anti-hypertensive treatment

The effects of anti-hypertensive treatments on sPRR, renin activity, and prorenin varied in the patients of this study. In patients with type 2 diabetes, treatment with ARBs only increased plasma sPRR in women, whereas ACEi increased PRA primarily in men. In contrast, regardless that all patients with type 2 diabetes treated with $\beta$-blockers displayed increased PRA, plasma sPRR was augmented only in women, but not in men.

In addition, despite anti-hypertensive treatment, no changes were found in urine sPRR in patients with type 2 diabetes. Urine renin activity was increased among men and women with type 2 diabetes treated with blood pressure medications. Interestingly, beta-blockers increased urine prorenin in diabetic men, but not in women counterpart. Furthermore, in these patients, the combined treatment with ACEi and ARBs was accompanied by increased urine prorenin only in men, whereas ACEi increased urine prorenin in women (Table 5). 
Table 4 Multiple regression analysis with eGFR

\begin{tabular}{|c|c|c|c|c|c|c|c|c|c|}
\hline \multirow[t]{2}{*}{ Predictors } & \multicolumn{3}{|c|}{ Urine Renin Activity } & \multicolumn{3}{|c|}{ Plasma sPRR } & \multicolumn{3}{|c|}{ Urine sPRR } \\
\hline & $\bar{\beta}$ & $t$ & $P$ value & $\bar{\beta}$ & $t$ & $P$ value & $\bar{\beta}$ & $t$ & $P$ value \\
\hline Model 1-constant & 94.47 & 49.29 & $<0.001$ & 100.52 & 20.55 & $<0.001$ & 86.11 & 41.58 & $<0.001$ \\
\hline Model 2-constant & 114.89 & 9.61 & $<0.001$ & 117.29 & 10.18 & $<0.001$ & 112.37 & 9.88 & $<0.001$ \\
\hline Type 2 diabetes & -3.79 & -0.89 & 0.377 & -5.19 & -1.39 & 0.1673 & -2.76 & -0.74 & 0.462 \\
\hline Age & -0.70 & -5.75 & $<0.001$ & -0.72 & -6.25 & $<0.001$ & -0.688 & -5.51 & $<0.001$ \\
\hline Sex & 3.09 & 1.02 & 0.307 & 3.81 & 1.40 & 0.1640 & 3.73 & 1.31 & 0.190 \\
\hline Race & -9.66 & -3.05 & 0.0026 & -11.67 & -4.01 & $<0.001$ & -11.89 & -4.01 & $<0.001$ \\
\hline Body weight (kg) & -0.06 & -0.18 & 0.010 & -0.486 & -1.83 & 0.073 & 2.69 & 2.52 & 0.012 \\
\hline BMl & 0.33 & 1.68 & 0.093 & 0.197 & 1.08 & 0.2829 & 0.17 & 0.92 & 0.359 \\
\hline DBP & 0.137 & 0.90 & 0.371 & 0.154 & 1.06 & 0.2887 & 0.22 & 1.42 & 0.158 \\
\hline SBP & -0.05 & -0.53 & 0.594 & -0.04 & -0.40 & 0.6877 & -0.09 & -0.92 & 0.359 \\
\hline Anti-hypertensives & -1.18 & -1.96 & 0.052 & -1.751 & -3.254 & 0.001 & -2.10 & -3.94 & $<0.001$ \\
\hline Anti-diabetic medications & 1.84 & 0.29 & 0.773 & 3.762 & 0.639 & 0.524 & 0.85 & 6.11 & 0.900 \\
\hline
\end{tabular}

Urine Renin Activity: Model 1: $P=0.0038, A$

Plasma sPRR: Model 1: $P=0.0058, R^{2}=3.4 \%$; Model 2: $P<0.001, R^{2}=25.67 \%$

Urine sPRR Model 1: $P=0.0357, R^{2}=3.4 \%$; Model 2 : $P=0.001, R^{2}=26.61 \%$

\section{Urine renin activity is an indicator of renal dysfunction in} patients with type 2 diabetes

Urinary excretion of AGT has been proposed as a biomarker of intrarenal RAS activation in patients with type 2 diabetes [2]. We further examined whether renin activity in the urine could be also considered a potential indicator of intrarenal RAS stimulation. Our results indicated that in patients with type 2 diabetes, urine renin activity increased as the concurrence of diabetes status, hypertension, eGFR $<60 \mathrm{~mL} / \mathrm{min}$ per $1.73 \mathrm{~m}^{2}$, and/or ACR also increased (Supplemental, Figure S1).

\section{Augmentation of UAGT is associated with high levels of sPRR in men but not women}

We further investigated the relationship between plasma sPRR and uAGT. Plasma sPRR did not correlate with uAGT excretion in all participants (Supplemental Figure S2A). However, when patients were divided into low plasma sPRR $(\leq 16 \mathrm{ng} / \mathrm{mL})$ and high plasma sPRR $(\geq 19$ $\mathrm{ng} / \mathrm{mL}$ ) groups, uAGT was significantly higher in those patients with greater levels of plasma sPRR than in patients with low levels (Supplemental Figure S2B). This difference was significant only in men $(P<0.02)$, but not in women $(P=0.73$; Supplemental, Figure $\mathrm{S} 2 \mathrm{C})$.

\section{Discussion}

The present study reveals important new findings regarding sex differences in the sPRR in patients with type 2 diabetes. (1) Patients with type 2 diabetes exhibit sex differences in sPRR concentrations in plasma and urine: (i) Plasma sPRR concentration is higher in women compared to men; (ii) Plasma sPRR correlates with age, BMI, eGFR, and PRA in women, but not in men; (iii) In contrast to plasma, urine sPRR concentrations are markedly decreased in both men and women. (2) Urine sPRR correlates with renin activity in both men and women; but it only correlates with age, BMI, glycemia, and eGFR in men, not in women. Our results also indicate that eGFR is associated with sPRR in plasma and urine, as well as with renin activity in urine after adjusting by age and race. (3) Renin activity in urine increases with the co-existence of increased ACR, hypertension, and reduced eGFR. (4) The effects of anti-hypertensive treatment on sPRR differ by sex: ARBs and $\beta$-blockers increase plasma sPRR in women but not in men, whereas ACEis increase PRA but not sPRR. In contrast, increase plasma SPRR was augmented only in women, but not in men. These findings have important clinical implications due to the potential role of sPRR as indicator of intrarenal RAS activation and renal dysfunction in men and women with type 2 diabetes.

Sex is a relevant biological variable in the prevalence and pathophysiology of CV diseases [28, 32]. Women with type 2 diabetes experience a disproportionately greater CV burden than men [4]. Interestingly, estrogens are beneficial to glucose homeostasis, and clinical trials also suggest that early menopause is associated with a higher risk of type 2 diabetes development compared to the average menopausal age [27]. Our results unveil the existence of a sexual dimorphism in the plasma concentrations of SPRR in healthy subjects and patients with type 2 diabetes. In this study, plasma sPRR and PRA were both significantly higher in women with type 2 diabetes as compared with their male counterparts. The mechanism by which estrogens increase plasma SPRR in postmenopausal women is not clear. It is possible that 
Table 5 Soluble PRR, renin, and prorenin in plasma and urine distributed by type of anti-hypertensive treatment

\begin{tabular}{|c|c|c|c|c|c|c|c|c|}
\hline \multirow[b]{3}{*}{ Total participants, $n$} & \multirow[t]{2}{*}{ Control } & \multicolumn{7}{|c|}{ Type 2 diabetes } \\
\hline & & No meds & ARBs & ACEi & $\mathrm{ARB} / \mathrm{ACE}$ & $\beta$-blockers & $\begin{array}{l}\text { Calcium } \\
\text { blockers }\end{array}$ & Diuretics \\
\hline & 167 & 25 & 13 & 30 & 4 & 19 & 1 & 4 \\
\hline \multicolumn{9}{|l|}{ Plasma } \\
\hline sPRR (ng/mL) & $16.6 \pm 4.1$ & $17.3 \pm 6.4$ & $21.8 \pm 9.8^{*}$ & $18.1 \pm 4.3$ & $23.3 \pm 7.0$ & $20.0 \pm 8.6$ & 11.9 & $22.7 \pm 4.1$ \\
\hline $\begin{array}{l}\text { Renin activity (ng Ang-l/mL/ } \\
\text { h) }\end{array}$ & $3.3 \pm 0.3$ & $13.2 \pm 2.0^{*}$ & $17.1 \pm 1.7^{*}$ & $11.8 \pm 1.7^{*}$ & $5.4 \pm 1.2$ & $10.0 \pm 1.7^{*}$ & 21.12 & $7.5 \pm 5.5$ \\
\hline \multicolumn{9}{|l|}{ Urine } \\
\hline sPRR/uCr (ng/mg) & $16 \pm 1.6$ & $0.95 \pm 0.8$ & $0.90 \pm 0.8$ & $0.81 \pm 0.9$ & $0.40 \pm 0.2$ & $1.0 \pm 1.4$ & 115 & $0.91 \pm 0.5$ \\
\hline $\begin{array}{l}\text { Renin activity (ng Ang-l/mL/ } \\
\text { h) }\end{array}$ & $26.9 \pm 36$ & $\begin{array}{l}102.1 \pm \\
102^{*}\end{array}$ & $51.46 \pm 44^{*}$ & $\begin{array}{l}96.89 \pm \\
105^{*}\end{array}$ & $\begin{array}{l}221.1 \pm \\
182^{*}\end{array}$ & $102.2 \pm 73^{*}$ & 273.8 & $50.12 \pm 23^{*}$ \\
\hline Prorenin/uCr (ng/g) & $\begin{array}{l}142.1 \pm \\
159\end{array}$ & $270.7 \pm 326$ & $\begin{array}{l}346.5 \pm \\
281.8\end{array}$ & $\begin{array}{l}275.5 \pm \\
236.1\end{array}$ & $\begin{array}{l}113.0 \pm \\
12.87\end{array}$ & $357 \pm 336^{*}$ & 1075 & $202 \pm 148$ \\
\hline Men, $n$ & 69 & 10 & 5 & 12 & 3 & 11 & 0 & 0 \\
\hline \multicolumn{9}{|l|}{ Plasma } \\
\hline sPRR (ng/mL) & $18 \pm 4.7$ & $16.3 \pm 5.0$ & $17.4 \pm 4.8$ & $18.2 \pm 4.7$ & $25.4 \pm 7.0$ & $17.0 \pm 6.2$ & - & - \\
\hline $\begin{array}{l}\text { Renin activity (ng Ang-1/mL/ } \\
\text { h) }\end{array}$ & $3.2 \pm 3.6$ & $13.2 \pm 12^{*}$ & $4.2(n=1)$ & $9.3 \pm 7.1^{\dagger}$ & $4.9 \pm 2.8$ & $6.5 \pm 3.3$ & - & - \\
\hline \multicolumn{9}{|l|}{ Urine } \\
\hline sPRR/uCr (ng/mg) & $1.4 \pm 1.2$ & $0.78 \pm 0.8$ & $0.4 \pm 0.5$ & $0.65 \pm 0.5$ & $0.36 \pm 0.25$ & $0.65 \pm 0.5$ & - & - \\
\hline $\begin{array}{l}\text { Renin activity (ng Ang-l/mL/ } \\
\text { h) }\end{array}$ & $15 \pm 17.6$ & $131.5 \pm 1.4^{*}$ & $\begin{array}{l}28.41(n= \\
1)\end{array}$ & $108 \pm 107^{*}$ & $308 \pm 142^{*^{\dagger}}$ & $105.8 \pm 52^{*}$ & - & - \\
\hline Prorenin/uCr (ng/g) & $120 \pm 97.2$ & $380 \pm 0.4$ & $\begin{array}{l}953.5(n= \\
1)\end{array}$ & $215 \pm 156$ & $113 \pm 12.9^{\ddagger}$ & $\begin{array}{l}520.2 \pm \\
388^{*}\end{array}$ & - & - \\
\hline Women, $n$ & 99 & 15 & 8 & 18 & 1 & 8 & 1 & 4 \\
\hline \multicolumn{9}{|l|}{ Plasma } \\
\hline sPRR (ng/mL) & $15.5 \pm 3.3$ & $17.8 \pm 7.3$ & $\begin{array}{l}24.5 \pm \\
11.3^{*}\end{array}$ & $18.1 \pm 4.2$ & 17.2 & $23.8 \pm 10^{* \dagger}$ & 12 & $22.7 \pm 4.2$ \\
\hline $\begin{array}{l}\text { Renin activity (ng Ang-l/mL/ } \\
\text { h) }\end{array}$ & $2.8 \pm 2.4$ & $13.2 \pm 8.0^{*}$ & $18.8 \pm 1.9^{*}$ & $13.3 \pm 8.4^{*}$ & 6.4 & $11.1 \pm 6.4^{*}$ & 21.12 & $7.5 \pm 9.7^{\ddagger}$ \\
\hline \multicolumn{9}{|l|}{ Urine } \\
\hline sPRR/uCr (ng/mg) & $0.95 \pm 0.08$ & $0.86 \pm 0.1$ & $1.2 \pm 0.1$ & $0.49 \pm 0.1$ & 0.53 & $1.5 \pm 0.2$ & 0.11 & $\begin{array}{l}0.780 \pm \\
0.61\end{array}$ \\
\hline $\begin{array}{l}\text { Renin activity (ng Ang-l/mL/ } \\
\text { h) }\end{array}$ & $19.5 \pm 22$ & $84 \pm 68^{*}$ & $54 \pm 45$ & $67.6 \pm 50^{*}$ & 46 & $97.6 \pm 98^{*}$ & 273 & $50.1 \pm 23$ \\
\hline Prorenin/uCr (ng/g) & $99.4 \pm 84.7$ & $207 \pm 198$ & $260 \pm 150$ & $\begin{array}{l}312.3 \pm \\
271^{*}\end{array}$ & - & $193.4 \pm 180$ & 1075 & $202 \pm 147$ \\
\hline
\end{tabular}

Data are expressed as mean \pm SD. $s P R R$ soluble prorenin receptor, $u C r$ urine creatinine. *Different from controls; Different from patient with type 2 diabetes: ${ }^{\dagger}$ no medication, ${ }^{\ddagger} \mathrm{ACEi},{ }^{\ddagger} \mathrm{ABRs}$

an interaction with the $G$ protein-coupled estrogen receptor (GPER) plays a significant role. Resveratrol, which can activate GPER [33], decreases PRR expression, profibrotic and pro-inflammatory proteins, and vascular remodeling in aging mice [34]. However, it has not been established whether GPER is protective in women with type 2 diabetes by decreasing circulating SPRR and PRRmediated $\mathrm{CV}$ alterations. Current studies are undergoing to clarify these issues. In different cohorts, plasma sPRR levels do not vary by sex, age, circadian rhythms, hormones, or diabetes status [22, 26]. However, in our study, plasma sPRR concentrations differed between men and women, particularly among subjects with diabetes. Most of our patients with type 2 diabetes were hypertensive, obese, or middle-aged. In women with essential hypertension, plasma sPRR correlates with age [22]. Full-length PRR is physically associated with the vacuolar $\mathrm{H}^{+}$-ATPase (V-ATPase) and traffics to the cell surface, whereas the sPRR is secreted to the extracellular compartment [16-18]. It is possible that plasma sPRR is increased in patients at middle age as a mechanism of compensation of PRR due to V-ATPase dysfunction and 
impaired autophagy during aging [22, 35]. Although in our study we did not measure plasma estrogen levels neither collect information on different phases of the menstrual cycle, it is possible that sex hormones may regulate sPRR in plasma and CV complications in subjects with type 2 diabetes $[22,26,36]$. The fact that women with type 2 diabetes exhibit decreased protection from estrogens is due, in part, to maladaptive RAS activation [4, 28], suggest that careful considerations should be given to increased levels of SPRR in the plasma, particularly in postmenopausal women because they are at higher risk of CV complications and development of diabetic kidney disease and end-stage kidney disease $[28,37]$. Similarly, prorenin is increased in the plasma of patients with type 2 diabetes, which is associated with the presence of microalbuminuria [29] and the onset of CV complications [38]. Previous studies have shown that plasma concentrations of prorenin and renin are elevated in obese women not receiving estrogen therapy when compared with those of postmenopausal women treated with hormone therapy [39]. However, whether sPRR contributes to the activation of prorenin in vivo has remained controversial $[11,40]$. More studies including subjects with $\mathrm{CV}$ and kidney diseases are needed to better define the clinical impact of plasma sPRR in CV complications, particularly in women with type 2 diabetes.

The concentrations of sPRR in the urine of patients with type 2 diabetes differ between men and women and may reflect local changes of intrarenal RAS activation. Elevated plasma sPRR levels may reflect decreased clearance of sPRR from the kidney [22]; since sPRR is a small molecule $(28 \mathrm{kDa})$ compared with albumin, it is easily filtered in the glomerulus, and plasma and urine concentrations should be in equilibrium. However, whether urinary SPRR is excreted without being absorbed from the proximal tubules is unclear. In the present study, we attempted to analyze the relationship between sPRR in urine and eGFR after correcting by risk factors of type 2 diabetes (Table 3). The demonstration that sPRR in urine-positive correlates with eGFR in men but not in women suggest that urine sPRR in men with type 2 diabetes might be associated with the stimulation of urine renin activity and eGFR decline over time. Although patients with essential hypertension seem to not display sexual dimorphisms in this regard, Ichihara and associates reported that plasma SPRR correlates positively with renal function independent of age, BP, and HbA1c [22]. These results support the fact that in patients with type 2 diabetes, the pathophysiology of renal injury is sexually dimorphic; because although women with type 2 diabetes are more susceptible to changes in eGFR and progression of end-stage kidney disease, the overall progression of the disease slows down compared to men
[29]. The underlying mechanism of this relationship is not clear and requires further investigation. Multiple regression analysis revealed that there is a significant association between eGFR with urine renin activity, and plasma and urine sPRR levels. In addition, we found a significant association between age, race, and antihypertensives with eGFR, which support the concept that eGFR declines with age and that African American participants have on average a decreased eGFR compared to Caucasians after adjusting for urine SPRR, diabetes mellitus status, age, sex, BMI, DBP, SBP, and medications. Interestingly, only men with type 2 diabetes displayed differences in renal dysfunction parameters which were correlated with urine SPRR. Urinary excretion of sPRR was negatively associated with age, BMI, and blood glucose in men, but not in women. However, HbA1c did not correlate with plasma and urine sPRR levels in patients with type 2 diabetes. Sautin et al. demonstrated that glucose promotes V-ATPase trafficking to plasma membrane in the renal epithelial cells [41]. Thus, these results suggest that glucose can stimulate the trafficking PRR/V-ATPase to the plasma membrane.

The urinary TGF- $\beta 1$ excretion is augmented in patients with type 2 diabetes and is associated with the progression of renal failure [42, 43]. These findings might be relevant to our study. It has been reported that the activation of PRR membrane-bound isoform by renin and prorenin stimulates TGF- $\beta 1$ [14]. In diabetes, the collecting duct is the main supplier of prorenin [44]. Here, we showed that in patients with type 2 diabetes, prorenin levels were increased in urine samples concentrated ten-fold before assaying. Given that prorenin is produced in large amounts by the collecting duct in diabetes [44], it is likely that PRR bound to cell plasma membranes is activated by locally produced prorenin, which could explain the increases in TGF- $\beta 1$ in urine during the progression of renal disease in the diabetic kidney. Future studies are warranted to examine the underlying mechanisms explaining the dissociation between plasma and urine sPRR concentrations in men and women with type 2 diabetes, and the impact on the stimulation of pro-inflammatory factors in kidney disease.

The activation of PRR in renal tubules contributes to the development of kidney injury in two different ways: directly via the stimulation of intracellular signals linked to fibrosis and inflammation $[5,8,9,14,15]$, and indirectly by leading to further formation of intrarenal/intratubular angiotensin-II (Ang-II) $[14,45,46]$. In mice with specific PRR deficiency in the collecting duct (CD), PRR for activation of locally generated prorenin, increases in renin activity, and contributes to the formation of $d e$ novo Ang-II in the lumen of the CD [46]. In the present study, patients with type 2 diabetes had greater increases 
in renin activity in the urine. Urine renin activity may reflect the severity of kidney dysfunction, which emphasizes its importance as a potential marker of maladaptive intrarenal/intratubular RAS activation in patients with type 2 diabetes. The fact that prorenin has been reported as undetectable in the urine $[47,48]$ is consistent with reabsorption of renin by the proximal tubules $[49,50]$ and that renin in urine does not reflect prorenin conversion to renin in the intratubular compartment $[50,51]$. Unfortunately, most of the studies reporting renin levels in urine utilize commercially available ELISA kits, which rely on prorenin as the standard provided. In these studies, renin levels in urine are reported at least ten-fold higher than those measured and referenced by the International Reference Preparation of human renin [52]. In the present study, the fact that renin activity measured by radioimmunoassay was increased in urine four- and three-fold in men and women with type 2 diabetes, respectively, suggests that active renin was probably generated further down in the distal nephron segments. Recent studies reported that megalin reabsorbs renin in the proximal tubules since megalin knockout mice exhibited excessive urinary excretion of renin [49, 50]. Megalin is primarily expressed in the apical brush border of the proximal tubules and contributes to reabsorption of filtered molecules [53]. Impairment of this process is the hallmark of the many forms of renal disorders, including DN [53]. Therefore, we cannot rule out that the augmentation of renin activity and prorenin in the urine of patients with type 2 diabetes is due to altered glomerular filtration and/or impaired proximal tubular reabsorption.

Anti-hypertensive treatments on sPRR, renin activity, and urine prorenin differ between men and women with type 2 diabetes. Renin activity in plasma increased by antihypertensive medications in subjects with diabetes [47]. In the present study, the fact that ARBs increase in plasma sPRR parallel augmentation of PRA support further support the concept that plasma sPRR is an indicator of systemic RAS activation in women with type 2 diabetes. In contrast, although diuretics increased renin activity in plasma and urine of patients with type 2 diabetes, primarily in women; these findings were not associated with changes in SPRR. Systemic and intrarenal RAS activation in patients with type 2 diabetes and hypertension may differ between men and women [54]. However, most studies focused on $\mathrm{CV}$ and renal responses to RAS blockade examine primarily male subjects, and studies including humans or animal of both sexes are scarce [55]. However, a few studies report reduced effectiveness of ARBs and ACEi in females. Modeling and analyses from male and female normotensive and hypertensive rats shows that ACEi and ARBs induce similar decreases in AT1R-bound AngII when expressed as percent change instead of absolute values [56]. Likewise, mathematical models predict preferential beneficial vasodilatory effects in women after treatment with ARBs as compared to ACEi, likely mediated via AT2R [57]. Further studies are required to elucidate the mechanisms underlying on the sex differences in the efficacy of anti-hypertensives.

We did not quantify the levels of Ang-II in urine, but the concomitant augmentation of renin activity and uAGT, particularly from men with type 2 diabetes, emphasizes the importance of intrarenal and intratubular RAS activation in the progression of DN and CKD [31]. Indeed, the inhibition of sodium-glucose cotransporter prevents the augmentation of intrarenal AGT and uAGT by mitigating renal tubular fibrosis and inflammation in mice [58] and humans [59] with type 2 diabetes. Although in the present study uAGT did not correlate with plasma sPRR in total participants, it did in men with type 2 diabetes. Furthermore, the fact that PRR is involved in the progression of mesangial fibrosis in patients with diabetic kidney disease [60] highlights the relevance of plasma sPRR as a potential biomarker of CKD. Clinical trials documenting that ACEi and ARBs treatments only slow down, but do not halt, the progression of CKD among patients with diabetic or non-DN [61] demonstrates the critical need for novel therapeutic targets in renal disease. Future studies are warranted to define the relevance of sPRR in the pathogenesis of CKD and its impact as a clinical biomarker for the identification of patients at a high risk for CKD.

\section{Limitations}

Our study has some limitations. Patients with type 2 diabetes were older and had higher BMI than control participants. Both age and obesity might influence the concentrations of sPRR in the plasma. Unfortunately, data on duration of hypertension and diabetes, collected information on different phases of menstrual cycle, menopause status, estrogen replacement therapy, and HbA1c levels, which were evaluated only in participants with the diagnosis of diabetes not in controls subjects, are not available. Further studies are warranted to measure sPRR at different time-points in pre- and perimenopause women and younger men in order to elucidate if plasma and urine SPRR concentrations could be used as predictors for the systemic and intrarenal RAS status, type 2 diabetes, and CKD onset and progression in men and women later in life. These studies will help to define the effects of sex hormones on plasma and urine sPRR concentrations and their impact on clinical outcomes in CVD.

\section{Conclusions}

Patients with type 2 diabetes exhibit sex differences in sPRR concentrations in plasma and urine. In diabetic 
women, increased plasma sPRR parallels the activation of systemic RAS; while in diabetic men, augmentation of sPRR in urine matches with intrarenal RAS stimulation. In patients with CV disease, sPRR might be a potential indicator of intrarenal RAS activation and renal dysfunction in men and women with type 2 diabetes.

\section{Perspectives and significance}

In patients with type 2 diabetes, high circulating levels of prorenin are associated with the onset of microalbuminuria and the occurrence of microvascular complications. The ability of sPRR to activate prorenin raises the possibility that the interactions between SPRR and prorenin in the systemic circulation, or within the kidney intratubular compartments, may contribute to either systemic or intrarenal RAS activation and progression of CKD in patients with type 2 diabetes. Data from the present study indicate that sPRR exhibit sexual dimorphisms in patients with type 2 diabetes. In these patients, increases in plasma sPRR parallel urine albumin/creatinine ratio, hypertension, and decline in renal function. Specifically, plasma sPRR concentration is higher in women as compared to men. In contrast to plasma, urine sPRR concentrations are markedly decreased in both men and women. Recently, it has been suggested that sPRR may exert beneficial effects on a rodent model of type 2 diabetes [62]. As stated by Yang and associates, the chronic infusion of recombinant sPRR-His in high-fat diet-induced type 2 diabetic mice decreased obesity, hyperglycemia, insulin resistance, and albuminuria. In this regard, since type 2 diabetes is a complex metabolic disease, it is possible that compensatory mechanisms counter sex and hormone effects by the increased sPRR levels. Furthermore, aging must be an additional factor that might contribute to metabolic status in response to changes in plasma sPRR [22]. Identifying the underlying mechanisms of sex disparities of sPRR and clinical outcomes would yield unique insights on the impact of sPRR on CV risk and kidney dysfunction in patients with type 2 diabetes.

\section{Supplementary Information}

The online version contains supplementary material available at https://doi. org/10.1186/s13293-021-00374-3.

\footnotetext{
Additional file 1: Supplementary Figure S1. Renin activity in urine by moderate loss of kidney function, hypertension (HTN) and albumin/ creatinine (ACR: urine albumin to creatinine ratio). Data are expressed as mean \pm Standard error of the mean (SEM). ${ }^{*} P=0.001$ different from control group, $+P<0.001$ different from group 2 (type 2 diabetes and HTN), $\neq$ different from group 3 (type 2 diabetes, HTN and ACR). Supplementary Figure S2. (A) Correlation between soluble prorenin receptor (SPRR) levels and urinary angiotensinogen (UAGT) excretion ( $r=$ 0.05; $P=0.42)$. Data are expressed as mean \pm SEM. Comparisons of UAGT between low $(\leq 16 \mathrm{ng} / \mathrm{mL})$ and high $(\geq 19 \mathrm{ng} / \mathrm{mL})$ levels of sPRR in patients with diabetes (B) and by gender (C). (C) ${ }^{*} P<0.02$. (D) Men $P=$ 0.03 and Women $P=0.73$
}

\section{Acknowledgements}

We thank the Molecular and Analytical Core of the Tulane Renal Hypertension Center of Excellence (TRHCE, Tulane University School of Medicine) for providing the physical infrastructure to perform some of the experiments. The authors also acknowledge the excellent technical assistance of Dale M. Seth and Akemi Katsurada (TRHCE). We also thank the critical review of Dr. Sarah H. Lindsey (Department of Pharmacology, Tulane University School of Medicine).

\section{Authors' contributions}

DYA, CRB, MAF, JH, CL, MJA, GD, JH, ACC, and TKT collected and processed the samples and/or performed the measurements. BV, DYA, CRB, TKT, JJ, EAJ, and MCP accomplished data analyses. BV, TKT, EAJ, JJL, FMJ, VAF, and MCP prepared the manuscript, tables and figures, and/or provided critical revisions of the manuscript and interpretation of the data. The author(s) read and approved the final manuscript.

\section{Funding}

The following awards provided funds for (1) MCP: (RO1-DK104375 from the National Institute of Diabetes and Digestive and Kidney (NIDDK); Tulane SOM Faculty Research Pilot Funds Program, UL1TR003096 from the National Center for Advancing Translational Sciences of the UAB-CCTS Partner Network Multidisciplinary Pilot Program, and Tulane SOM Faculty Pilot Fund); (2) MCP and TKT :(K12HD043451 from the Eunice Kennedy Shriver National Institute of Child Health \& Human Development of the Building Interdisciplinary Research Careers in Women's Health (BIRCWH) Program; (3) VAF: (The TullisTulane Alumni Chair in Diabetes for VAF). (4) MCP, TKT, and VAF: (U54 GM104940 from the National Institute of General Medical Sciences, which funds the Louisiana Clinical and Translational Science, LACaTs); (5) FMJ: (NIDDK awards R01-DK074970, R01-DK107444, a Department of Veterans Affairs Merit Review Award, \#BX003725 and the Tulane Center of Excellence in Sex-Based Biology \& Medicine); (6) EAJ: (from the National Cancer Institute and RO1-DK114321 from the NIDDK). (7) DYA was recipient of the Coordenaऽão de Aperfeisoamento de Pessoal de Nivel Superior (CAPES) from Brazil. (8) ACC and $\mathrm{JH}$ were recipients of the Ramadhyani-Bourgeois, MD Student Endowed Fund Award.

\section{Availability of data and materials}

The data and analyses of this study are available from the corresponding author on reasonable request.

\section{Declarations}

\section{Ethics approval and consent to participate}

This study protocol was approved by Tulane Institutional Review Board (\#13460293E) and written informed consent was obtained for all participants.

Consent for publication

Not applicable.

\section{Competing interests}

The authors declare that they have no competing interests.

\section{Author details}

${ }^{1}$ Department of Physiology, Tulane University School of Medicine, 1430

Tulane Avenue, SL39, New Orleans, LA 70112, USA. ²Department of Medicine, Endocrinology Division, Tulane University School of Medicine, New Orleans, LA, USA. ${ }^{3}$ AdventHealth, Translational Research Institute, Orlando, FL, USA. ${ }^{4}$ Department of Biostatistics and Data Science, School of Public Health and Tropical Medicine, New Orleans, LA, USA. ${ }^{5}$ Renal Service, Memorial Sloan Kettering Cancer Center, New York, NY, USA. ${ }^{6}$ Southeast Louisiana Veterans Healthcare System, New Orleans, LA, USA. ${ }^{7}$ Tulane Center of Excellence in Sex-Based Biology and Medicine, New Orleans, LA, USA. ${ }^{8}$ Tulane Hypertension and Renal Center of Excellence, Tulane University School of Medicine, New Orleans, LA, USA. 
Received: 6 October 2020 Accepted: 7 April 2021 Published online: 01 May 2021

\section{References}

1. Alicic RZ, Rooney MT, Tuttle KR. Diabetic kidney disease: challenges, progress, and possibilities. Clin J Am Soc Nephrol. 2017;12(12):2032-45. https://doi.org/10.2215/CJN.11491116.

2. Kobori H, Kamiyama M, Harrison-Bernard LM, Navar LG. Cardinal role of the intrarenal renin-angiotensin system in the pathogenesis of diabetic nephropathy. J Investig Med. 2013;61(2):256-64. https://doi.org/10.2310/JIM. Ob013e31827c28bb.

3. Fan YY, Kobori H, Nakano D, Hitomi H, Mori H, Masaki T, et al. Aberrant activation of the intrarenal renin-angiotensin system in the developing kidneys of type 2 diabetic rats. Horm Metab Res. 2013;45(5):338-43. https:// doi.org/10.1055/s-0032-1331256.

4. Peters SA, Huxley RR, Woodward M. Diabetes as a risk factor for stroke in women compared with men: a systematic review and meta-analysis of 64 cohorts, including 775,385 individuals and 12,539 strokes. Lancet. 2014; 383(9933):1973-80. https://doi.org/10.1016/S0140-6736(14)60040-4.

5. Nguyen G, Delarue F, Burckle C, Bouzhir L, Giller T, Sraer JD. Pivotal role of the renin/prorenin receptor in angiotensin II production and cellular responses to renin. J Clinlnvest. 2002;109(11):1417-27.

6. Nabi AH, Kageshima A, Uddin MN, Nakagawa T, Park EY, Suzuki F. Binding properties of rat prorenin and renin to the recombinant rat renin/prorenin receptor prepared by a baculovirus expression system. Int J Mol Med. 2006; 18(3):483-8.

7. Nurun NA, Uddin NM, Nakagawa T, Iwata H, Ichihara A, Inagami T, et al. Role of "handle" region of prorenin prosegment in the non-proteolytic activation of prorenin by binding to membrane anchored (pro)renin receptor. Front Biosci. 2007;12(12):4810-7. https://doi.org/10.2741/2429.

8. Zhang J, Noble NA, Border WA, Owens RT, Huang Y. Receptor-dependent prorenin activation and induction of PAl-1 expression in vascular smooth muscle cells. Am J Physiol Endocrinol Metab. 2008;295(4):E810-9. https://doi. org/10.1152/ajpendo.90264.2008

9. Gonzalez AA, Zamora L, Reyes-Martinez C, Salinas-Parra N, Roldan N, Cuevas $C A$, et al. (Pro)renin receptor activation increases profibrotic markers and fibroblast-like phenotype through MAPK-dependent ROS formation in mouse renal collecting duct cells. Clin Exp Pharmacol Physiol. 2017;44(11): 1134-44. https://doi.org/10.1111/1440-1681.12813.

10. Advani A, Kelly DJ, Cox AJ, White KE, Advani SL, Thai K, et al. The (Pro)renin receptor: site-specific and functional linkage to the vacuolar $\mathrm{H}+$-ATPase in the kidney. Hypertension. 2009;54(2):261-9. https://doi.org/10.1161/ HYPERTENSIONAHA.109.128645.

11. Gonzalez AA, Lara LS, Luffman C, Seth DM, Prieto MC. The soluble form of the prorenin receptor $[S(P R R)]$ is augmented in the collecting ducts and in the urine of angiotensin II (Ang II)-dependent hypertensive rats. Hypertension. 2011;57(4):859-64. https://doi.org/10.1161/HYPERTENSIONA HA.110.167957.

12. Takemitsu T, Ichihara A, Kaneshiro Y, Sakoda M, Kurauchi-Mito A, Narita T, et al. Association of (pro)renin receptor mRNA expression with angiotensinconverting enzyme mRNA expression in human artery. Am J Nephrol. 2009; 30(4):361-70. https://doi.org/10.1159/000232199.

13. Takahashi K, Yamamoto H, Hirose T, Hiraishi K, Shoji I, Shibasaki A, et al. Expression of (pro)renin receptor in human kidneys with end-stage kidney disease due to diabetic nephropathy. Peptides. 2010;31(7):1405-8. https:// doi.org/10.1016/j.peptides.2010.04.003.

14. Huang J, Matavelli LC, Siragy HM. Renal (pro)renin receptor contributes to development of diabetic kidney disease through transforming growth factor-beta1-connective tissue growth factor signalling cascade. Clin Exp Pharmacol Physiol. 2011;38(4):215-21. https://doi.org/10.1111/j.1440-1681.2 011.05486.x

15. Ichihara A, Sakoda M, Mito-Kurauchi A, Itoh H. Activated prorenin as a therapeutic target for diabetic nephropathy. Diabetes Res Clin Pract. 2008; 82(Supplement 1):S63-S6.

16. Cousin C, Bracquart D, Contrepas A, Corvol P, Muller L, Nguyen G. Soluble form of the (pro)renin receptor generated by intracellular cleavage by furin is secreted in plasma. Hypertension. 2009;53(6):1077-82. https://doi.org/1 0.1161/HYPERTENSIONAHA.108.127258.

17. Nakagawa T, Suzuki-Nakagawa C, Watanabe A, Asami E, Matsumoto M, Nakano $M$, et al. Site-1 protease is required for the generation of soluble (pro)renin receptor. J Biochem. 2017;161(4):369-79. https://doi.org/10.1093/ $\mathrm{jb} / \mathrm{mvw} 080$.

18. Yoshikawa A, Aizaki Y, Kusano K, Kishi F, Susumu T, lida S, et al. The (pro)renin receptor is cleaved by ADAM19 in the Golgi leading to its secretion into extracellular space. Hypertension research : official journal of the Japanese Society of Hypertension. 2011;34(5):599-605. https://doi.org/1 $0.1038 / \mathrm{hr} .2010 .284$.

19. Hamada K, Taniguchi Y, Shimamura Y, Inoue K, Ogata K, Ishihara M, et al. Serum level of soluble (pro)renin receptor is modulated in chronic kidney disease. Clin Exp Nephrol. 2013;17(6):848-56. https://doi.org/10.1007/s10157013-0803-y.

20. Nishijima T, Tajima K, Takahashi K, Sakurai S. Elevated plasma levels of soluble (pro)renin receptor in patients with obstructive sleep apnea syndrome: association with polysomnographic parameters. Peptides. 2014; 56:14-21. https://doi.org/10.1016/j.peptides.2014.03.008.

21. Thomason J, Reyes M, Allen SR, Jones RO, Beeram MR, Kuehl TJ, et al. Elevation of (pro)renin and (pro)renin receptor in preeclampsia. Am J Hypertens. 2015;28(10):1277-84. https://doi.org/10.1093/ajh/hpv019.

22. Morimoto $S$, Ando $T$, Niiyama M, Seki $Y$, Yoshida N, Watanabe D, et al. Serum soluble (pro)renin receptor levels in patients with essential hypertension. Hypertension research : official journal of the Japanese Society of Hypertension. 2014;37(7):642-8. https://doi.org/10.1038/hr.2014.46.

23. Deinum J, Rønn B, Mathiesen E, Derkx FH, Hop WC, Schalekamp MA. Increase in serum prorenin precedes onset of microalbuminuria in patients with insulin-dependent diabetes mellitus. Diabetologia. 1999;42(8):1006-10. https://doi.org/10.1007/s001250051260.

24. Davies L, Fulcher GR, Atkins A, Frumar K, Monaghan J, Stokes G, et al. The relationship of prorenin values to microvascular complications in patients with insulin-dependent diabetes mellitus. J Diabetes Complications. 1999; 13(1):45-51. https://doi.org/10.1016/S1056-8727(98)00020-8.

25. Luetscher JA, Kraemer FB, Wilson DM, Schwartz HC, Bryer-Ash M. Increased plasma inactive renin in diabetes mellitus. A marker of microvascular complications. N Engl J Med. 1985;312(22):1412-7. https://doi.org/10.1056/ NEJM198505303122202.

26. Nguyen G, Blanchard A, Curis E, Bergerot D, Chambon Y, Hirose T, et al. Plasma soluble (pro)renin receptor is independent of plasma renin, prorenin, and aldosterone concentrations but is affected by ethnicity. Hypertension. 2014;63(2):297-302. https://doi.org/10.1161/HYPERTENSIONA HA.113.02217.

27. Mauvais-Jarvis F, Manson JE, Stevenson JC, Fonseca VA. Menopausal hormone therapy and type 2 diabetes prevention: evidence, mechanisms, and clinical implications. Endocr Rev. 2017;38(3):173-88. https://doi.org/1 0.1210/er.2016-1146

28. Colafella KMM, Denton KM. Sex-specific differences in hypertension and associated cardiovascular disease. Nat Rev Nephrol. 2018;14(3):185-201. https://doi.org/10.1038/nrneph.2017.189.

29. Shepard BD. Sex differences in diabetes and kidney disease: mechanisms and consequences. Am J Physiol Renal Physiol. 2019;317(2):F456-F62. https://doi.org/10.1152/ajprenal.00249.2019.

30. Levey AS, Bosch JP, Lewis JB, Greene T, Rogers N, Roth D. A more accurate method to estimate glomerular filtration rate from serum creatinine: a new prediction equation. Modification of Diet in Renal Disease Study Group. Ann Intern Med. 1999;130(6):461-70. https://doi.org/10.7326/0003-4819-130-6-1 99903160-00002.

31. Mills KT, Kobori H, Hamm LL, Alper AB, Khan IE, Rahman M, et al. Increased urinary excretion of angiotensinogen is associated with risk of chronic kidney disease. Nephrol Dial Transplant. 2012;27(8):3176-81. https://doi. org/10.1093/ndt/gfs011.

32. Du T, Fernandez C, Barshop R, Guo Y, Krousel-Wood M, Chen W, et al. Sex differences in cardiovascular risk profile from childhood to midlife between individuals who did and did not develop diabetes at follow-up: the bogalusa heart study. Diabetes Care. 2019;42(4):635-43. https://doi.org/1 0.2337/dc18-2029.

33. Dong $\mathrm{WH}$, Chen JC, He YL, Xu JJ, Mei YA. Resveratrol inhibits K(v)2.2 currents through the estrogen receptor GPR30-mediated PKC pathway. Am J Physiol Cell Physiol. 2013;305(5):C547-57. https://doi.org/10.1152/ajpcell. 00146.2013

34. Kim EN, Kim MY, Lim JH, Kim Y, Shin SJ, Park CW, et al. The protective effect of resveratrol on vascular aging by modulation of the renin-angiotensin system. Atherosclerosis. 2018;270:123-31. https://doi.org/10.1016/j.a therosclerosis.2018.01.043. 
35. Binger KJ, Muller DN. Autophagy and the (pro)renin receptor. Front Endocrinol (Lausanne). 2013;4:155. https://doi.org/10.3389/fendo.2013.00155.

36. Watanabe N, Morimoto S, Fujiwara T, Suzuki T, Taniguchi K, Mori F, et al. Prediction of gestational diabetes mellitus by soluble (pro)renin receptor during the first trimester. J Clin Endocrinol Metab. 2013;98(6):2528-35. https://doi.org/10.1210/jc.2012-4139.

37. Barsha G, Denton KM, Mirabito Colafella KM. Sex- and age-related differences in arterial pressure and albuminuria in mice. Biol Sex Differ. 2016; 7(1):57. https://doi.org/10.1186/s13293-016-0110-x.

38. Deinum J, Tarnow L, van Gool JM, de Bruin RA, Derkx FH, Schalekamp MA et al. Plasma renin and prorenin and renin gene variation in patients with insulin-dependent diabetes mellitus and nephropathy. Nephrol DialTransplant. 1999;14(8):1904-11. https://doi.org/10.1093/ndt/14.8.1904.

39. Danser AH, Derkx FH, Schalekamp MA, Hense HW, Riegger GA, Schunkert H. Determinants of interindividual variation of renin and prorenin concentrations: evidence for a sexual dimorphism of (pro)renin levels in humans. J Hypertens. 1998;16(6):853-62. https://doi.org/10.1097/00004872-1 99816060-00017.

40. Danser $\mathrm{AH}$. The role of the (pro)renin receptor in hypertensive disease. Am J Hypertens. 2015;28(10):1187-96. https://doi.org/10.1093/ajh/hpv045.

41. Sautin YY, Lu M, Gaugler A, Zhang L, Gluck SL. Phosphatidylinositol 3kinase-mediated effects of glucose on vacuolar H+-ATPase assembly, translocation, and acidification of intracellular compartments in renal epithelial cells. Mol Cell Biol. 2005;25(2):575-89. https://doi.org/10.1128/ MCB.25.2.575-589.2005.

42. Sato H, Iwano M, Akai Y, Kurioka H, Kubo A, Yamaguchi T, et al. Increased excretion of urinary transforming growth factor beta 1 in patients with diabetic nephropathy. Am J Nephrol. 1998;18(6):490-4. https://doi.org/10.11 59/000013415.

43. Shaker YM, Soliman HA, Ezzat E, Hussein NS, Ashour E, Donia A, et al. Serum and urinary transforming growth factor beta 1 as biochemical markers in diabetic nephropathy patients. Beni-Suef Univ J Basic Appl Sci. 2014;3(1):1623. https://doi.org/10.1016/j.bjbas.2014.02.002.

44. Kang JJ, Toma I, Sipos A, Meer EJ, Vargas SL, Peti-Peterdi J. The collecting duct is the major source of prorenin in diabetes. Hypertension. 2008;51(6): 1597-604. https://doi.org/10.1161/HYPERTENSIONAHA.107.107268.

45. Ichihara A, Sakoda M, Kurauchi-Mito A, Nishiyama A, Itoh H. Involvement of receptor-bound prorenin in development of nephropathy in diabetic $\mathrm{db} / \mathrm{db}$ mice. J Am Soc Hypertension. 2009;2(5):332-40.

46. Prieto MC, Reverte V, Mamenko M, Kuczeriszka M, Veiras LC, Rosales CB, et al. Collecting duct prorenin receptor knockout reduces renal function increases sodium excretion, and mitigates renal responses in ANG IIinduced hypertensive mice. Am J Physiol Renal Physiol. 2017;313(6):F1243F53. https://doi.org/10.1152/ajprenal.00152.2017.

47. van den Heuvel M, Batenburg WW, Jainandunsing S, Garrelds IM, van Gool $J M$, Feelders RA, et al. Urinary renin, but not angiotensinogen or aldosterone, reflects the renal renin-angiotensin-aldosterone system activity and the efficacy of renin-angiotensin-aldosterone system blockade in the kidney. J Hypertens. 2011;29(11):2147-55. https://doi.org/10.1097/HJH.0b013 e32834bbcbf.

48. Tang J, Wysocki J, Ye M, Valles PG, Rein J, Shirazi M, et al. Urinary renin in patients and mice with diabetic kidney disease. Hypertension. 2019;74(1): 83-94. https://doi.org/10.1161/HYPERTENSIONAHA.119.12873.

49. Tojo A, Kinugasa S, Fujita T, Wilcox CS. A local renal renin-angiotensin system activation via renal uptake of prorenin and angiotensinogen in diabetic rats. Diabetes Metab Syndr Obes. 2016;9:1-10. https://doi.org/1 0.2147/DMSO.S91245.

50. Sun Y, Lu X, Danser AHJ. Megalin: a novel determinant of renin-angiotensin system activity in the kidney? Curr Hypertens Rep. 2020;22(4):30. https://doi. org/10.1007/s11906-020-01037-1.

51. Roksnoer LC, Heijnen BF, Nakano D, Peti-Peterdi J, Walsh SB, Garrelds $I M$, et al. On the origin of urinary renin: a translational approach. Hypertension. 2016;67(5):927-33. https://doi.org/10.1161/HYPERTENSIONA HA.115.07012.

52. Roksnoer LC, Verdonk K, Garrelds IM, van Gool JM, Zietse R, Hoorn EJ, et al. Methodologic issues in the measurement of urinary renin. Clin J Am Soc Nephrol. 2014;9(7):1163-7. https://doi.org/10.2215/CJN.12661213.

53. Schuh CD, Polesel M, Platonova E, Haenni D, Gassama A, Tokonami N, et al. Combined structural and functional imaging of the kidney reveals major axial differences in proximal tubule endocytosis. J Am Soc Nephrol. 2018; 29(11):2696-712. https://doi.org/10.1681/ASN.2018050522.
54. Maranon R, Reckelhoff JF. Sex and gender differences in control of blood pressure. Clin Sci (Lond). 2013;125(7):311-8. https://doi.org/10.1042/CS2013 0140.

55. Tamargo J, Rosano G, Walther T, Duarte J, Niessner A, Kaski JC, et al. Gender differences in the effects of cardiovascular drugs. Eur Heart J Cardiovasc Pharmacother. 2017;3(3):163-82. https://doi.org/10.1093/ehjcvp/pvw042.

56. Leete J, Gurley S, Layton A. Modeling sex differences in the renin angiotensin system and the efficacy of antihypertensive therapies. Comput Chem Eng. 2018;112:253-64. https://doi.org/10.1016/j.compchemeng.2018. 02.009 .

57. Leete J, Layton AT. Sex-specific long-term blood pressure regulation: modeling and analysis. Comput Biol Med. 2018;104:139-48. https://doi.org/1 0.1016/j.compbiomed.2018.11.002.

58. Woods TC, Satou R, Miyata K, Katsurada A, Dugas CM, Klingenberg NC, et al. Canagliflozin prevents intrarenal angiotensinogen augmentation and mitigates kidney injury and hypertension in mouse model of type 2 diabetes mellitus. Am J Nephrol. 2019;49(4):331-42. https://doi.org/10.1159/ 000499597.

59. Yoshimoto T, Furuki T, Kobori H, Miyakawa M, Imachi $H$, Murao K, et al. Effects of sodium-glucose cotransporter 2 inhibitors on urinary excretion of intact and total angiotensinogen in patients with type 2 diabetes. J Investig Med. 2017;65(7):1057-61. https://doi.org/10.1136/jim-2017-000445.

60. Narumi K, Sato E, Hirose T, Yamamoto T, Nakamichi T, Miyazaki M, et al. (Pro)renin receptor is involved in mesangial fibrosis and matrix expansion. Sci Rep. 2018;8(1):16. https://doi.org/10.1038/s41598-017-18314-w.

61. Lewis EJ, Hunsicker LG, Clarke WR, Berl T, Pohl MA, Lewis JB, et al. Renoprotective effect of the angiotensin-receptor antagonist irbesartan in patients with nephropathy due to type 2 diabetes. N Engl J Med. 2001; 345(12):851-60. https://doi.org/10.1056/NEJMoa011303.

62. Wang F, Luo R, Zou CJ, Xie S, Peng K, Zhao L, et al. Soluble (pro)renin receptor treats metabolic syndrome in mice with diet-induced obesity via interaction with PPARgamma. JCI Insight. 2020;5(7):7. https://doi.org/10.11 72/jci.insight.128061.

\section{Publisher's Note}

Springer Nature remains neutral with regard to jurisdictional claims in published maps and institutional affiliations.
Ready to submit your research? Choose BMC and benefit from:

- fast, convenient online submission

- thorough peer review by experienced researchers in your field

- rapid publication on acceptance

- support for research data, including large and complex data types

- gold Open Access which fosters wider collaboration and increased citations

- maximum visibility for your research: over $100 \mathrm{M}$ website views per year

At BMC, research is always in progress.

Learn more biomedcentral.com/submissions 